\title{
1. Watching this space, West Papua
}

Commentary: President Joko Widodo's announcement in May 2015 that Indonesia would allow foreign journalists to have access to West Papua was widely, but cautiously, welcomed. Some journalists decided to have another attempt at getting into this region, long cordoned off to outside access. The labyrinthine process of applying for a journalist visa was a warning that change does not happen overnight for West Papuan media freedom. On the ground, it is a risky business for a journalist covering West Papua. Local independent journalists, especially, face regular threats. The attackers are empowered by the knowledge that there is no formal accountability processes over intimidation and the murder of journalists or media workers. However, there appears to be a genuine hope that President Jokowi's term in office represents a small window of opportunity for improvement for Papua. The handling of journalists and media freedom in West Papua is very much a test case for this. Watch this space.

Keywords: bureaucracy, Indonesia, journalism, media freedom, Melanesia, New Guinea, police, West Papua

\section{JOHNNY BLADES}

Journalist, Radio New Zealand International

- HE ANNOUNCEMENT in May 2015 by Indonesian President Joko Widodo that he was lifting the ban on foreign media entering West Papua was applauded abroad. International media organisations rightly praised the move, although some were possibly rather too quick to uncork the champagne. The Pacific Freedom Forum enthused that years of pressure were finally starting to pay off:

It seems that the word has finally gone out from Jakarta to the military thugs in Jayapura and beyond - leave the media alone. (PFF, 2015)

But generally the optimism was tempered with caution. The West Papua commentariat had come to expect media subterfuge from regional governments seeking to deflect attention from the serious and long-running lack of access to Indonesia's eastern region, not just for journalists, but also for foreign researchers, humanitarian and social workers. 
The caution seemed to be justified when, following President Widodo's comments, ministers in his own government poured cold water on the suggestion that access to Papua would be easier. The Coordinating Minister for Political, Legal and Security Affairs, Tedjo Edhy Purdijatno, explained that foreign journalists seeking permits to cover Papua would be screened, monitored and forbidden from certain areas (presumably the Highlands). He warned foreign media not to seek false information from armed groups about security forces' violations.

'So, let the journalists have a firsthand glimpse of the situation in Papua. There is no news alike what is reported by the overseas media,' he said, adding that government was no longer using a repressive security approach in Papua, but instead one with a welfare focus. (Antara, 2015)

University of Indonesia international law expert Hikmahanto Juwana suggested that foreign journalists who entered Papua, and their media outlets, would be subject to sanctions from the Indonesian Press Council 'if found guilty of violating the journalistic code of ethics' (Salim et al, 2015).

\section{Clearing house}

It had been standard Indonesian government practice to deny that there was a ban on foreign media in West Papua. This was technically true, but in reality, securing permission to go to Papua was exceedingly rare as it required approval from 12 separate state agencies, including the military, which met each week at a Clearing Committee managed by the Ministry of Foreign Affairs to consider such applications. The clearing house process had been in effect since the early days of the Suharto rule and proved most convoluted to negotiate. As one diplomat in Jakarta put it, 'even Jesus Christ cannot get the permit to go to Papua' (Harsano, 2015).

However, in the last fseveral years a few foreign journalists had made it to Papua, such as Mark Davis of SBS and Fairfax's Michael Bachelard. In 2014, Davis examined whether Papua was experiencing a 'new dawn', having returned to Papua 15 years after he had ventured into the jungles of Irian Jaya to find out about the hidden independence struggle (Davis, 2014). Bachelard, a Jakarta correspondent, went to Papua twice and produced a series of incisive articles. One looked at how West Papuan children were being removed to Islamic religious schools in Java for 're-education'(Bachelard, 2013). Another focused on the failings of the Papua public service on the region's AIDS epidemic (Bachelard, 2013b).

Other foreign journalists went via the riskier route of entering West Papua without permits to work. In August 2014, two French journalists working for German television channel Arte, Thomas Dandois and Valentine Bourrat, were arrested in West Papua when found by police to be working without a permit in the Highlands. Their swift detention in Jayapura immediately seized international headlines. The pair faced a five-year jail term for violating their tourist 
visas and their efforts to interview elements of the independence movement also landed at least one Papuan in indefinite custody. Foreign journalists caught working without a proper permit in Indonesia were usually promptly deported, but at this time, the tail end of Susilo Bambang Yudhoyono's term in office in late 2014, Indonesian authorities were sending a signal to foreign media ahead of the presidential elections. In the end the pair were given a two and a half month jail sentence.

Rohan Radheya is a Dutch journalist who has visited West Papua several times in recent years to work undercover, spending time with the OPM Free Papua Movement as well as political prisoners. His work resulted in the documentary film Melanesian Dreams (Apro productions, 2015). Despite the huge personal risk he took, Radheya was mindful of the risk for Papuans he met and interviewed.

'When I approach people ... they feel somehow that they have to talk to me because they are Papuans and they are occupied and they have a sort of a duty to talk to me,' he told Radio New Zealand International. 'They can be in prison for talking to me, and that's something I have to be very careful about.' (Blades, 2015b).

Despite the announcement by President Widodo (who is known widely as Jokowi) about the lifting of the ban on foreign journalists, Radheya was skeptical about the prospects for improvement. If anything, he felt Indonesia was seeking to exert more control over foreign journalists who visited Papua, monitoring and restricting movement, including meeting with the opposition in rural areas.

And that is exactly the problem: foreigners are restricted from travelling to rural areas. There's much lawlessness, much corruption in those areas, and that's where the human rights violations take place. That's actually the hotspot. It's like the security forces, they have a blank cheque, they can do whatever they want. They get away with it too. It's very difficult to know what's happened there, there's no internet, no telephone coverage, the roads are not good. So these are actually the hotspots where the security forces, the military, are committing the most human rights violations. (Blades, 2015b)

During Jokowi's term of office so far, the focus has largely been around fostering economic development in those parts of Papua where basic services were lacking. In this, his policy has not been too dissimilar to his predecessor, Yudhoyono. However, it has quickly become clear that Jokowi is taking a different approach on West Papua by travelling more frequently to the remote region to take a handson approach to development, including efforts to actually listen to Papuans. The most visible gestures he has made include talking about opening up media access and freeing political prisoners.

Much like his predecessor, Jokowi downplayed suggestions of ongoing 'separatist' troubles in West Papua. However, the 'what conflict?' angle is hard to 
reconcile with the steady stream of ground reports about abuses against Papuans by security forces. Many of these reports have been hard to verify, hence the need to have better access to the region to produce accurate reports about claims of atrocities and other serious matters. Indonesian diplomats have claimed that security risks in West Papua made it too dangerous for foreign journalists to venture there. However, this simply does not stack up with assertions by Jakarta that Papua is a peaceful region where it is making significant efforts to foster economic development for the indigenous people to participate in.

Officials I met at the Indonesian Embassy in New Zealand felt there was often a lack of understanding about Indonesia in New Zealand. One of their criticisms was that New Zealand media had a negative perception about the country. In the case of Radio New Zealand International's coverage of West Papua, they felt we did not often enough incorporate the Indonesian government voice in our reports. It was probably a fair call, but this imbalance was not for want of trying. Making contact with Indonesian government officials or security forces spokespeople in Papua has long been a problem because of the remoteness of the place, its patchy telecommunications and the language barrier. There is also a defensiveness that Jakarta exhibits around Papua-related matters which is not easily traversed from afar. We wanted to hear and see their side of the story, if only they would let us. After all, I was interested to see some of the efforts to nurture economic development in Papua which I had read so much about in Indonesian media in recent years.

I had previously been declined for a visa to West Papua. However, after the May announcement, I decided to give it another attempt. The process was still convoluted. My fraught experience of the application process may serve as a useful example of how Indonesia currently handles media freedom and journalism in West Papua.

\section{The place that sends you mad}

The complex process of applying for a journalist visa as well as for a permit to shoot video for my colleague Koroi Hawkins and I, led me in and out of the Indonesian Embassy in Wellington half a dozen times through the bitter winter of 2015. Because more was required than just filling in the Indonesian Foreign Ministry's online forms, an official at the embassy guided me through the requirements of the application, which included a detailed reporting schedule, list of interviewees and letters of recommendation from local officials and interviewees.

The embassy official assured me of his help in applying for a permit to Papua, but was keen to first build a friendship, or trust, as he put it. So there were several meetings with cups of tea and discussions about New Zealand media perceptions of Indonesia. Early on, he offered a place on the upcoming Indonesian Foreign 
Ministry's journalist visitor's programme which involved prescribed visits for overseas-based journalists to Bandung, Bali and Jakarta, featuring scheduled interviews with government officials. I declined, preferring to focus on Papua.

Getting hold of people in Papua and pinning them down months in advance for an interview was challenging. A lot of e-mails and phone messages were dispatched through intermediaries, but there were few replies. I noted that Papuan church figures were usually good communicators; Indonesian officials less soperhaps because their grasp of English tended to not be as good as the Papuans.

It sometimes took a month to get answers, so it seemed a minor victory when I received a signed letter from the Governor of Papua province, Lukas Enembe, endorsing our visit. Still, the official at the embassy felt I would need more letters to get over the line. Among the people I hoped to interview were leading Indonesian government and security forces figures. I made no headway with the police or military, but I managed to get through to one of the key Jakarta people, Judith Dipodiputro, a sort of special envoy for President Jokowi on community development in Papua.

It had been relatively easy to contact Dipodiputro via WhatsApp, an app favoured by many in Indonesia. Over the phone she agreed to be interviewed, due to the fact that she would probably be in Jayapura the same time as our planned trip there. That seemed straightforward enough. When I included her name on our submission, the official at the Indonesian Embassy said that I would need a letter of recommendation from Dipodiputro in order to get an interview. I went back and tried to contact Dipodiputro, but she was busy. Things drifted for a few weeks before I received a message from her to contact her assistant in Jakarta to request the interview. Through him, I learned that a letter of recommendation was needed from my manager at RNZI before Dipodiputro could produce a letter from her end: a government requirement, apparently. Next, I was asked for interview questions to be sent in advance. I did as required, although a letter of recommendation from the Indonesian side was not forthcoming.

Separate from the journalist visa, the video permit, we were told, would have to be issued by the Badan Koordinasi Penanaman Modal (BKPM), Indonesia's state agency for coordinating investment. This seemed strange, given the journalistic nature of our planned trip. It was not some commercial piece. Contacts in Jakarta believed there was still some confusion about the directive from President Jokowi that foreign media were to be given access to Papua. There were no clear instructions on how this was to be implemented. An unwieldy network of ministries and state agencies with different agendas simply kept operating as they had long done.

The same embassy official I was dealing with had also facilitated journalists' visa applications for two other New Zealand journalists, Adrian Stevanon and Karen Abplanalp, to go to Papua in August, for Māori Television, filming a programme 
about the indigenous people of West Papua, including material from the Highlands town of Wamena. (Abplanalp was also completing her master's degree thesis on media access to West Papua [Abplanalp, 2015]). After seeing the preview for their programme, the embassy official was sweating about how Māori Television's portrayal of Papua would go down with his superiors. He was worried too about being held responsible for helping RNZ International in case it did further harm. His job could be on the line, the official suggested. He reminded me about comments made by the Indonesian Ambassador, Joses Tavares, that Jakarta had no problem with foreign journalists covering Papua, as long as the coverage was 'independent'.

We finally heard from the embassy official that he had sent the papers off to Jakarta for the application to be considered by the committee and it was only a day later that we heard back that our journalist visas were approved. But then things got complicated with the BKPM. When it transpired that our man at the embassy had not sent off our application for a video permit until shortly before we were due to go to Papua, I started to get worried. Abplanalp and Stevanon had been told they had to travel to Jakarta to personally pick up their video permit. Otherwise, they would have probably flown via Denpasar, Bali. On the other hand, I sought to travel to West Papua via Papua New Guinea. The embassy official, who had offered to send through the papers for our video permit applications, said that it might be possible to not have to travel to Papua via Jakarta, and recommended I organise a friend or colleague to pick up the permit from the BKPM in the Indonesian capital and then send it to me. I therefore organised an expatriate New Zealand journalist who I knew who was living in Jakarta to do this pick-up. But when the time came to collect the permit, the agency told him it did not have enough information about the purpose of our planned visit to Papua to give approval. This required more exchanges and in the meantime the BKPM started asking my contact in Jakarta questions about the aim of our plans. This man was in fact merely picking up the permit as a functionary and was not privy to our reporting plans. Yet suddenly he was in the firing line. The BKPM's suspicion about my plans for Papua made him distinctly uneasy. Down the phone line from Jakarta, he explained to me in no uncertain terms that the authorities could make his ability to live and work in Indonesia difficult if it turned out that Koroi and I had a 'secret agenda'. I was aghast at the thought of implicating him through our reporting. What if our coverage of Papua somehow caused the authorities in Jakarta to knock on this man's door one night and tear him away from his young family? There was no secret agenda on our part, but I felt another layer of pressure being built into the Papua trip.

The official spoke about our applications needing to go through proper channels, but there were so many of them and they were so inefficient. It had begun to feel like The Twelve Tasks of Asterix where one of a set of Herculean challenges facing the protagonist leads him and his offsider, Obelix, into a 
bureaucratic office complex to seek a particular permit, only for staff to direct them up and down floors, back and forth between more 'clinically unhelpful people' in a never-ending wild goosechase that would drive mere mortals steadily insane (Goscinny et al, 1978).

Regarding the elusive video permit, our friend at the embassy said not to worry, that it was just communication issues between the BKPM and the Foreign Ministry. I took it that his late despatch of our papers had been part of this. The BKPM approved the permit, simply sending an electronic copy the day before we left for Papua. Presumably we could have done it this way all along. As if to underline the lack of cohesiveness in this whole process, I found that while the vaunted letter of recommendation from Judith Dipodiputro's people had still not been issued after a month of communications, a simple call to her on our way in to New Guinea was all it took to seal the arrangement. For her part, she was happy to meet and talk about Jokowi's development drive. Mandarins had merely complicated everything. Throughout the bureaucracy there seemed to be suspicion that foreign journalists were some sort of destabilising agents.

\section{Glimpses}

We went into Papua by land via Indonesia's border with Papua New Guinea, the only international land border in the Pacific Islands region. The main border access point at Wutung is tightly guarded by Indonesian military. It is the same land but the differences between Papua New Guinea and West Papua come sharply into focus as you cross over to the western side, especially the presence of military and police. Without permission, we were not allowed to film or photograph the security forces. My earlier communications to seek interviews with the regional commanders had fallen short. But they knew we were coming.

Shortly before we had arrived, local journalists in Jayapura had a briefing from police and military about foreign journalists. In attendance was Victor Mambor, the editor and publisher of West Papuan independent newspaper Tabloid Jubi. Mambor was our fixer and guide while we visited Papua, just as he had been for Māori Television and for France 24's Cyril Payen. I had met Mambor at the 2013 Melanesian Spearhead Group leaders' summit in Noumea. He was doing more than any other West Papua journalist in recent years to cover the wider Pacific region and to bring the stories of Papuans to the wider Pacific region. He had travelled to New Zealand in 2014 lobbying for support for freedom of media access to Papua (Majavu, 2014). At the Jayapura briefing, police had warned about local agents working on behalf of foreigners. Mambor, a veritable interface to West Papua for us foreign journalists, had no doubt that they were referring to him.

Mambor was one of a handful of journalists who accompanied Jokowi around Papua during the president's May 2015 visit to Papua. While he may have been 


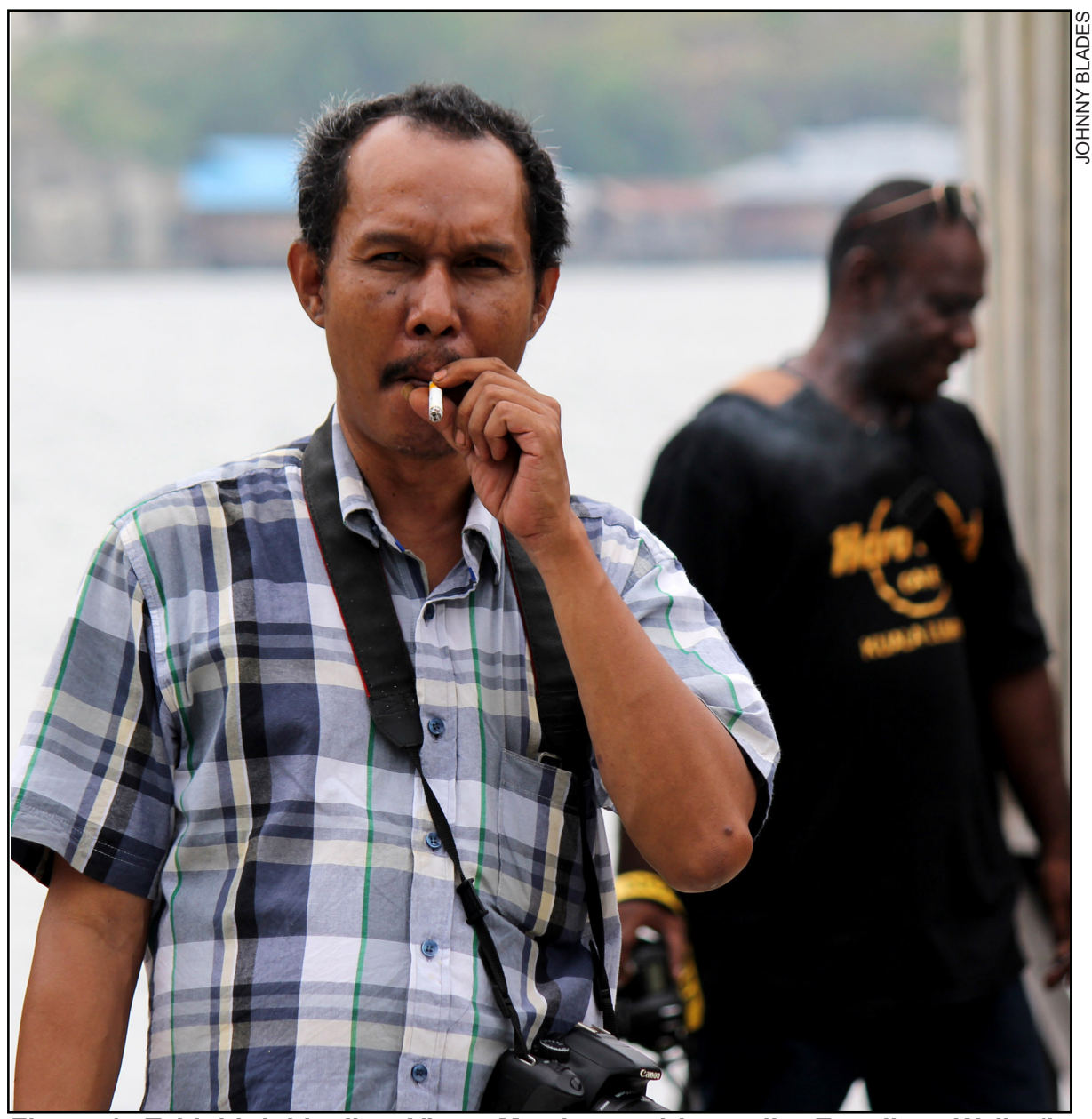

Figure 1. Tabloid Jubi editor Victor Mambor and journalist Engelbert Wally (in background) at Lake Sentani.

considered acceptable to the Jokowi administration, officials in the embassy in New Zealand, for instance, considered Mambor anti-government. Yet Mambor was not so much anti-government as pro-Papuan, chiefly concerned with disinterring West Papuan stories that were otherwise veiled by a Jakarta-spun version of events. Jakarta, he knew, was keeping an increasingly close watch on international coverage. We expected in advance that intelligence agents would be watching our steps. Sure enough, each morning in Jayapura I opened the curtains in the hotel room and noticed a couple of men in the square, keeping an eye on us. I came to expect them, and when I waved, they waved back.

In West Papua, we met a good range of people: Papuans and non-Papuans; government officials, people on the street, fishermen, public servants, the political prisoner Filep Karma. Some were cautious about speaking on tape. Beyond Papuans' 
aspirations for independence, there is a clear sentiment among the indigenous people of Indonesia's eastern region that the time is well overdue for mature discussion in Indonesia about basic human conditions and rights denied to them. Papuans see little reason why they should be branded as 'separatists' just for speaking up about Papua's core problems such as transmigration, the presence of security forces and the culture of impunity around military and police abuses.

However, the situation in West Papua is not set in stone. The old stereotype of the Papuan freedom fighter waging jungle warfare against the Indonesian state is less useful these days. There is an emerging generation more focused on advancing the Papuan cause through peaceful means, including social empowerment. There are plenty of non-Papuans who also want a non-military solution. There seems to be genuine hope that Jokowi's term represents a small window of opportunity for improvement in Papua. Media freedom is a testing ground for this, with the likes of Victor Mambor on the front line.

I work for my people here, I deliver the truth. Sometimes because we wrote the story of what West Papua wants, we get stigmatised by the authorities, especially police and military. One of my journalists was killed in Merauke. Then last month, one of my journalists got shot at... intimidated and harassed by police. So this is conflict land. Anything can happen. I know the risk, but we have a commitment to facing the risks. Young journalists have the same conviction as me. (V. Mambor, interview with author, 17/10/15)

Dian Kandipi is a journalist with Antara news agency. She told me working in West Papua carried risk. 'If you are not be careful, you can lose your life, lose your safety, lose your career' (Kandipi, 2016). Kandipi claimed she had generally

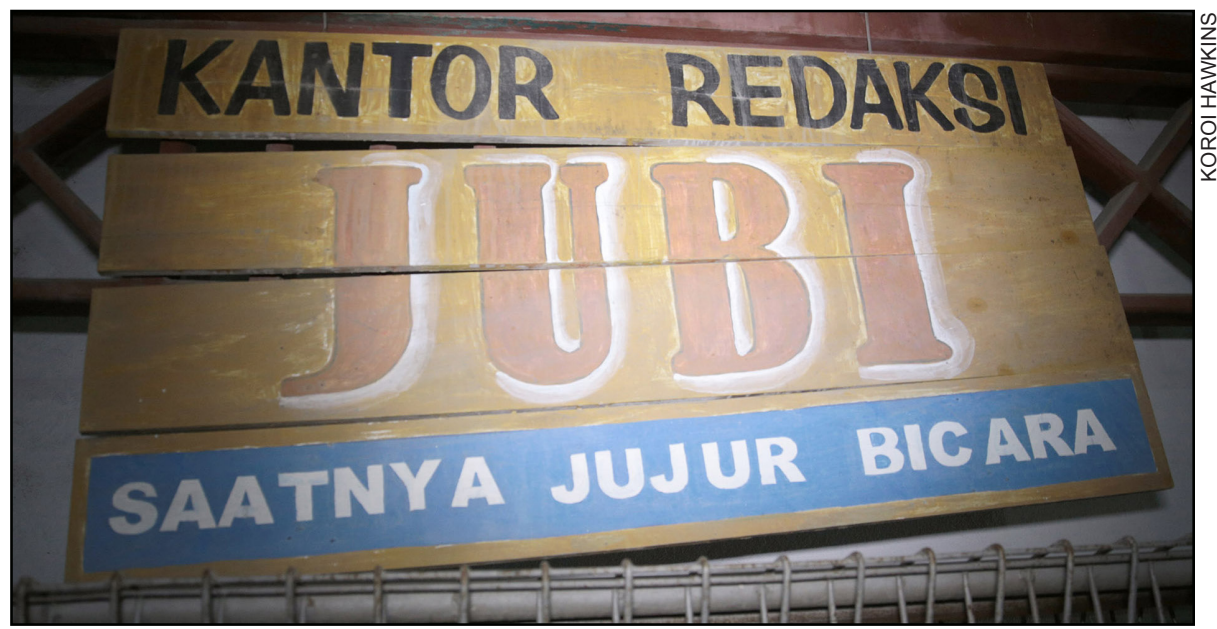

Figure 2. The Tabloid Jubi office in Jayapura, Papua. 
been able to cover a range of issues, but that media freedom came with what the journalist described as a requirement of 'clarification'.

'Sometimes, people in Papua do not understand about clarification, so if we wrong or false write a news, they can threaten our family or our self' (Kandipi, 2016).

False information spreads readily throughout Papua. Bribing journalists is relatively common. This comes into context when misleading reports surface in Indonesian national media about perpetrators of violence in the region where it has long been easy to pin blame on Papuan 'separatists'. However, it is clear that Indonesia can no longer control the flow of information in West Papua the way it used to. Social media has witnessed the mushrooming of West Papua solidarity amid busy information feeds carrying grisly reports of abuses from Papua. The growing international interest in Papua is something Jakarta is scrambling to manage. Jokowi and his core team at least seem to have realised that cordoning off West Papua to outside journalists appears repressive.

In November 2015, an international delegation of representatives of 10 media and freedom of expression organisations visited Indonesia at the invitation of the Alliance of Independent Journalists to investigate the state of the country's media and advocate for improvement. They made a stop in Papua which was found to be among the most concerning parts of the republic, media freedom-wise.

'Indonesia's existing climate of impunity continues to impact negatively on journalist safety and working conditions,' the delegation reported. 'Attackers are empowered by the knowledge that there are currently no formal accountability processes on investigations into attacks, intimidation and murder of journalists and media workers' (CPJ, n.d.). It also noted the obstacles to foreign journalists' reporting in Papua including surveillance and threats against their sources; finding that 'in some cases arrests of sources have taken place' (CPJ, n.d.).

While in Papua, we had a brush with police, when we went to a provincial volleyball tournament that the Papua Governor was formally opening. The place was crawling with police, perhaps because both the Papua police and military commanders were also in attendance. We were there to interview Governor Enembe, but police quickly swooped on us to check our papers. They were in order, but our plans to interview Enembe had to be put on hold for a few hours after a problem arose with police from General Paulus Waterpauw's office. They told me we had failed to report to the police upon entry to Papua. I explained that the Indonesian Embassy had assured me there was no requirement to do this. Besides, the command already knew about our presence because I had been communicating with Waterpauw in patchy Bahasa by text message a few days earlier, trying (unsuccessfully) to tee up an interview with the head policeman.

We were eventually cleared by police and subsequently directed by Governor Enembe to interview him back at his residence where it seems he was more at 
liberty to answer questions, away from the commanders. But while things were in limbo at the stadium, police and undercover personnel hovered around me, one of them making bizarre conversation with me, asking if I read the Bible; another gesturing shooting actions. It was intimidating stuff.

'See what we go through all the time?' said Victor Mambor that evening.

The visit to West Papua was just a glimpse, but it was most instructive (Blades, 2015a). My admiration for independent journalists based in Papua has only grown. The need for adequate support and protection for them to be able to do their job is even more important than the need for foreign journalists' access to Papua.

The step taken by President Jokowi to ease restrictions on media access in Papua was a welcome move. However, he is something of a lone figure on this, beholden to leading elements in his party and the parliament. It is felt by some Jakarta insiders that the president has not issued clear enough instructions on the media issue. Different ministries appear to be unsure of the change of process, or are determined to delay and frustrate foreign media applications because that is how it has always been done. To add to the confusion, the security forces-which are beyond civilian control in Papua — have their own ideas.

Meanwhile, Jakarta has refused Cyril Payen another visa to return to Papua and at the time of writing, I had just received the first communication in months from the official at the Indonesian Embassy in Wellington. He emailed a questionnaire on perceptions within New Zealand about Indonesia. The bid for greater understanding of each other continues.

\section{References}

Abplanalp, K. (2015). Media restrictions on Papua: Understanding the impacts. An exegesis and microsite submitted as part of an unpublished Master of Communication Studies at Auckland University of Technology, Auckland, NZ. Antara News (2015, May 12). Jokowi administration opens foreign media access to Papua. Retrieved on February 27, 2016, from www.antaranews.com/en/news/98896/ jokowi-administration-opens-foreign-media-access-to-papua

Apro Productions (2015) Melanesian Dreams. Available at: http://melanesiandreams. com/trailer/

Bachelard, M. (2013a, May). They're taking our children. Fairfax Media. Retrieved on February 27, 2016, from www.smh.com.au/lifestyle/theyre-taking-our-children20130428-2inhf

Bachelard, M. (2013b, February 9). Forgotten people of epidemic's last outpost. Fairfax Media.

Blades, J. (November 8, 2015a, November 8). Jakarta cautiously lifts veil in West Papua. Radio New Zealand. Available at: www.radionz.co.nz/national/programmes/insight/ audio/201777672/insight-for-8-november-2015-west-papua

Blades, J. (2015b, June 19). Dutch journo confronts dangerous task of reporting in Papua. Retrieved on February 27, 2016, from www.radionz.co.nz/international/ 
programmes/datelinepacific/audio/201759011/dutch-journo-confronts-dangeroustask-of-reporting-in-papua

Committee for the Protection of Journalists. (n.d.). Observations and Recommendations of the International Partnership Mission to Indonesia. Retrieved on February 27, 2016, from https://cpj.org/blog/IndonesiaMJ.pdf

Davis, M. (2014, June 3). West Papua's new dawn? [Video documentary]. Available at: www.sbs.com.au/news/dateline/story/west-papuas-new-dawn

Goscinny, R. \& Uderzo, A. (1978). The twelve tasks of Asterix. London: Hodder Children's Books.

Harsono, A, (2015, January 12). Papuans have heard Jokowi's promise but is the president listening? Jakarta Globe. Retrieved in February 27, 2016, from http://jakartaglobe. beritasatu.com/opinion/papuans-heard-jokowis-promises-president-listening/

Kandipi, D. (2016, January 20). Correspondence with the author.

Majavu, A. (2014, August 1). Visiting West Papua editor appeals for real 'open door' for foreign media. Pacific Media Centre's Pacific Scoop. Retrieved on February 27, 2016, from http://pacific.scoop.co.nz/2014/08/visiting-west-papua-editor-appealsfor-real-open-door-for-foreign-media/

Mambor, V. (2015, October 17). Interview with the author, Jayapura, Papua.

Pacific Freedom Forum. (2015, May 11). Papua promise a win for press freedom PFF. Retrieved on February 27, 2016, from http://pacific288.rssing.com/browser. php? ind $=19338148 \&$ item $=67$

Salim, T. and Aritonang, M. (2015, May 27). Jokowi's ministers reluctant to open up Papua, The Jakarta Post. Retrieved on February 27, 2016, from www.thejakartapost. com/news/2015/05/27/jokowi-s-ministers-reluctant-open-papua.html

Johnny Blades is a senior journalist with Radio New Zealand International who has written and reported on Melanesia for 15 years and is currently writing a book about Melanesian politics.

blades.johnny@gmail.com 